\title{
Social Work Profession and Disaster Risk Reduction in Pakistan
}

\author{
Sajjad Hussain \\ \& \\ Muhammad Ibrar \\ Department of Social Work \\ University of Peshawar

\section{Hamid Alam} \\ Department of Social Work \\ University of Malakand
}

\begin{abstract}
There is a long history of Social Work, helping the weaker sections of society and those who are affected by disasters - natural or man-made. Historical records reveal that social workers have been part of the disaster relief, recovery and rehabilitation efforts because they are equipped with the required knowledge and skills. The purpose of this study is to get acquaintance about the need and importance of social work profession in disaster risk reduction in Pakistan. In addition, it also identifies the responsibilities of professional social worker in disaster mitigation and management. This study concludes that Pakistan, due to its geographical and climatic conditions is faced with disasters like earthquake, floods, windstorms, avalanches, cyclones, storms, droughts, landslides, tsunamis and epidemics. Therefore, social workers have to play an effective role in pre and post disaster period. The study recommends that social workers should make their theoretical base strong by equipping themselves with up-dated knowledge, skills and use of the new techniques of social work for the rehabilitation of individuals, groups and communities affected by the disasters.
\end{abstract}

Keywords: Pakistan, Disaster, Social Work, Preparedness, Rehabilitation.

$$
\begin{aligned}
& \text { تلخيص }
\end{aligned}
$$

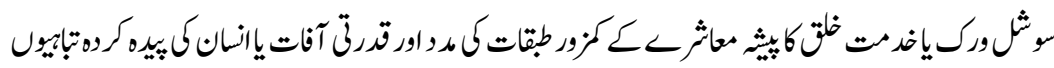

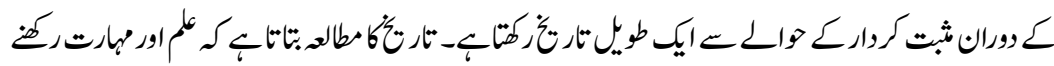

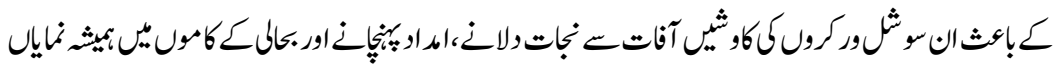

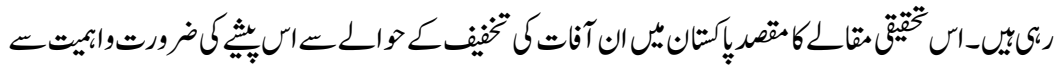

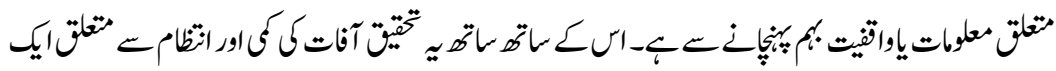

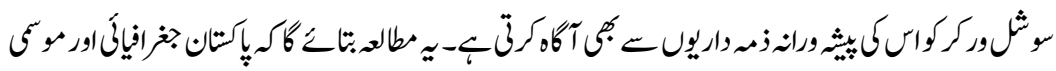




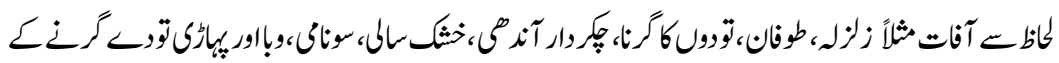

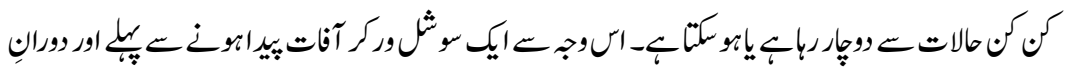

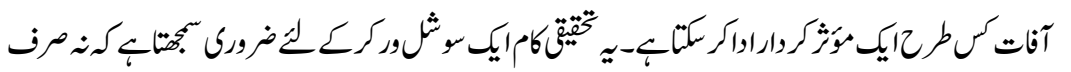

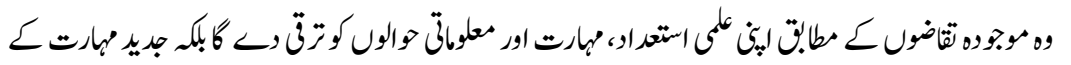

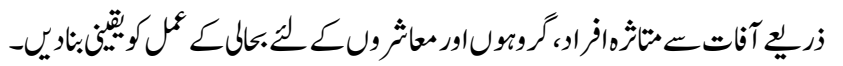

$$
\begin{aligned}
& \text { كليرى الفاط: باكتان، آفات،بوشلورك،يّارى،بحال }
\end{aligned}
$$

\section{Introduction}

Disaster may be defined as the grave commotion of the functioning of society, causing widespread damages to the humans and material losses, which is beyond the capacity local communities to deal with in the existing capacities. Disasters happen when the adverse effects of hazards are not handled properly (Abarquez and Murshed, 2004). While hazard can be defined as a dangerous event, substance, or phenomenon which may inflict loss to human lives, properties, economic resources and environmental conditions (U.N International Strategy for Disaster Reduction, 2009).

Disaster Mitigation and Risk Reduction (DRR) is an organized way of conceiving, measuring and reducing the risk. Generally, the purpose of DRR is to decrease fragilities and disaster risks in the society to avoid, decrease and plan for the undesirable impacts of natural hazards, as well as to make development sustainable (UNICEF, 2011).

Carlos Flores, the former president of Honduras was moved by the devastations made by Hurricane Mitch in 1998. He spoke these unforgettable and important words: "we lost in 72 hours what we have taken more than 50 years to build" (Ali, 2017). Pakistani people have also gone through the same situation during the last few decades due to its geo-physical conditions, and exposure to extreme climatic conditions. The occurrences of some of these incidents is not very frequent while other hazards like earthquake and tsunamis, though uncommon, but are very fatal and results in heavy loss to lives and property (Iqbal, 2012). Moreover, natural disasters; man-made dangers like manufacturing plants and vehicles pollution, fires, both in forest and cities; and civil agitations are threat to both the Pakistani economy and its environment (The Asia-Pacific Disaster Report, 2012).

Pakistan's northern areas are at increased risk of earthquakes, floods, cyclones, storms, landslides and avalanches (Adnan, 2014). The seismic activity in 2005 and 2013, and catastrophic floods in 2010, 2011 and 2012 inflicted heavy loss to the national economy and to lives as well. Similarly as a result of Military Operation 
against the outlaws in Federally Administered Tribal Areas (FATA) and Khyber Pakhtunkhwa province, hundreds of thousands more were compelled to leave their homes and shift to other safe places inside the country (Pakistan Floods 2011- Early Recovery Frame Work).

In 2012, heavy monsoon rains struck a population of 5 million and caused destruction of agricultural lands in upper parts of Sind, Southern areas of Punjab and some localities of Baluchistan, that had caused four hundred and forty deaths and damages to hundreds of thousands houses (Pakistan and UN, 2012).

Like other countries of the region, Pakistan has also introduced various measures for pre-and post-disaster situations which are reviewed below:

\section{Policy Measures at the National Level for Disaster Risk Reduction}

The National Disaster Risk Reduction Policy provides guidelines for dealing with the disasters that threaten Pakistani society. The policy includes both man-made and natural devastations and includes measures to redesign the important steps and ensure future development process and strengthen resilience (National Disaster Management Authority, 2013). Pakistan has also signed the UN Hyogo Framework for Action (HFA) 2005-2015. The main purpose of HFA is the merger of risk reduction as essential part of national policy and development agenda (Pakistan and UN, 2012). The Pakistan's ill preparedness for disasters exposed by the earth quack of 2005 and prompted a change in the response focussed to the present more vibrant approach. This change was highlighted in the National Disaster Management Ordinance, 2006 (that was substituted by National Disaster Management Act 2010). It is further followed up by the 'National Disaster Risk Management Framework, 2007-2012, that delineated a comprehensive national DRR programme. The newest DRR policy's building blocks demonstrate the essential programme of HFA, and are main component of the NDM Act 2010, which resulted in decentralization of responsibilities for DRR implementation to the district and provinces as well. This plan stresses on working not only with the local and national level departments but also closely with non-government organizations and other concerned partners (National Disaster Management Authority, 2013).

This article outlines how social work profession can contribute to disaster reduction. In addition the contribution of social workers in preparedness, response, recovery and rehabilitation are reviewed. The gaps in social work disaster knowledge and intervention are also highlighted.

\section{Main Objectives of the Study}

The purpose of study is to investigate the importance and need of social work profession in minimizing disaster risk. Furthermore, the study also examines 
the role of social workers' preparation to disasters, assistance, mitigation, rehabilitation and recovery of affected individual and community.

\section{Methodology of the Study}

The study is based on the review of available literature, stressing the need and requirements of social work interventions in disaster risk reduction. For this purpose, literature review was carried out with the help of relevant books, articles, internet and newspapers sources.

\section{Literature Review Social Work and Disaster Risk Reduction}

Social work profession is based on the values of social justice, equality, diminishing and abolition of all sorts of differences. To promote this perspective and deal with disasters, the profession should adopt pro-social development policies based on human rights principles (Harding, 2007). The role of social worker is not limited to the solution of social problems rather the scope of the profession is much wider and includes assistance to individuals, groups and disaster affected communities. In addition social work services consists of giving input in policies for disaster response, relief, prevention, mitigation and rehabilitation. Furthermore, social work interventions endeavours to deal with traumatic situations, treating the patients with abnormal mental conditions, planning and implementing interventions at the time of natural, man-made and industrial hazards (Soliman and Rogge, 2002). The current literature emphasizes the social work's role in grassroots and local level responses to the individual impacts about natural disasters, emphasizing community-driven development and address disasters situation (Farquhar and Dobson, 2004).

The profession of social work is originated from local and proletarian movements that commonly take care of sudden blows and use the strengths i.e. the resources of the vulnerable people (Mathbor, 2007). Social worker's participation in disaster management is important in linking the susceptible communities to required resources and relevant organizations during and after a disaster. National Association of Social Workers (NASW) outlined the responsibilities of social workers by focusing on socio-economic inequalities and disparities while addressing disaster like situations (Stoesen, 2006).

Social work is a profession and discipline based on the principles of social justice and human rights. Participation of social worker in disaster mitigation and management is vital for designing strategies that link the target communities to the relevant organizations and resources before and during the disaster. Social Work profession, by making the best use of the concept of social capital e.g. 
harmony, cohesion, interaction, social solidarity, capacity-building of individuals, communities and local groups to make certain social change and development (Loeffler et al., 2004). International organizations like Department for International Development UK(1997 and 2000) and the World Bank has carried out many projects for better performance of its projects using social capital (Nakagawa and Shaw, 2004). Recently, a special working group was organized by the Japan International Cooperation Agency(JICA) on social capital, to learn about the theory and possible implications for JICA projects. The group proposed the importance of creating synergy between government and community for sustainable development in its study report (JICA 2002). It is clear that social capital can play an effective role in disaster preparedness .United communities can more effectively deal with hazards as members voluntarily participate in problems solution (Yamamura 2010). Due to the increasing numbers of disasters both natural and man-made, social work profession has also developed certain roles and responsibilities for social workers in pre-and post disaster periods.

\section{Duties and Responsibilities of Social Workers in Disaster Risk Reduction}

Both from private and public sectors, the responsibilities and duties of social workers may be categorised into two areas: rescue and rehabilitation. Dodds and Nuehring (1996) believe that social workers' roles and responsibilities are important in all phases of a disaster management cycle. This comprises devising and execution of cyclical plan of mitigation, response, preparedness and recovery. Taking into consideration the importance and need of social work in minimizing hazards risk, Margareta Wahlström, stressed on the important role of social workers in disaster risk reduction while addressing to the participants of the European Association of Schools of Social Work (EASSW). She said "You can be the transmission chain" (Fowler, 2015).

Social workers have delivered and are contributing to DRR practice directly and indirectly by providing relief and counselling services to people facing disaster situation, assisting them in getting health and education facilities (Wahlstrom, 2017). Social workers perform the most important task of fulfilling the special needs of vulnerable groups, most importantly provision of temporary shelter during the response period. While according to Gillespie (2006) social workers should be prepared in anticipation rather than waiting till disaster occurs. Traditionally the social workers should be present at the disaster sites to extend help in the response and recovery efforts. At the recovery stage (micro and macro-levels) social worker's job is to plan recovery and rehabilitation, devise assistance programs and chalk up grants proposals to the donors (Javadian, 2007). The duties and responsibilities of professional social workers have been summarised as under: 


\section{Assisting Individuals and Families}

By this way the social worker provide material assistance, counselling and support after disaster for weaker sections of society including persons with disabilities, children, senior citizens to join activities and make available psychoemotional therapy to individuals and families in shelters, assist the families in funeral and burial arrangements, visiting homes of the affected people and organizing therapeutic interviews with the families of the victims (Yueh, 2003).

\section{Referral Services about Government Compensation Package and Access to Resources}

This consists of linkages between the government functionaries and the nongovernmental organizations, identification of needs and the needy people, collecting donations, distribution of food and non-food items and the registration of affected people with the relevant government departments (Wahlstrom, 2017). After every disaster, the government announces compensation package for the affected people in cash for the reconstruction/repair of their houses and agricultural land. As majority of the rural people lack knowledge about the compensation packages, therefore these people usually remain deprived of this financial assistance (Provincial Disaster Management Authority, 2016). In such cases, the role of social worker is to perform the role as a bridge between the target community, government, NGOs and donors for getting maximum financial assistance for the rehabilitation of the victims.

\section{Provision of Psychosocial Support}

Provision of psycho-social support is very important during disaster response and rehabilitation process. This includes conducting counselling session with disaster affected people like grief counselling and relief counselling, referring patients to therapists and therapeutic centres. The counselling sessions depends on the severity of mental and emotional problems (Australian Institute for Disaster Resilience, 2011). According to Javadian (2007) psychosocial support, which was previously less important to those affected by either the natural or man-made disasters, is now considered a major part of any useful emergency response.

The social worker by observing the code of ethics of social work, provide emotional and psychological support to those affected by the sudden loss to life and properties. The duty of social worker in this situation is to motivate these demotivated people and give them a new hope of life (Pryce \& Pryce, 2000).

\section{Improve Client Well-Being}

This role of social worker consists of advocating for change in government programs, mobilizing volunteers, carrying out needs assessment, allowing for 
distribution centres for victims and revising welfare programs to develop the capacity of community to meet their basic needs and requirements. Guided by social work principles of people's right to self- determination, participatory development methodology should be adopted while working for the welfare of the target communities (Lyons, Hokenstad, Pawar, Huegler, Hall, 2012). Social workers can play the role of advocate for equal treatment of all people especially who are facing oppression, discrimination and the displaced women and children. In addition the social workers, work with the communities to reintegrate children and stress for their rights to play and receive education (Syeda, \& Adnan, 2016).

The social worker has to perform multiple tasks for inclusion of voiceless people in the decision making process, aid distribution and provision of psycho-social interventions. Social work profession can manage disaster risk reduction by strengthening resilience and meaningfully involving vulnerable groups including women (Lyons, Hokenstad, Pawar, Huegler, Hall, 2012).

\section{Community Based Disaster Risk Management}

Disaster risk reduction plans and endeavours cannot be carried out by an individual, rather it needs concerted efforts on the part of community, government and civil society organizations (World Health Organization, 2015). Although governmental and non-governmental organizations try their best to deliver services at the time of disasters, but the sustainability of such initiatives depends on the meaningful participation of the target community (Abarquez, and Murshed, 2004). Social workers believe in the utilization of the available resources of the target community with their active participation for sustained results (Ali, 2005). As government rehabilitation process has to pass through official procedures which is a cumbersome process, so a social workers can facilitate the individuals and community to make them self -reliant in this period of time.

In this context social workers perform their responsibilities as moderator, motivator, capacity enhancer to make community members participate in disaster management process for creation of sense of ownership and sustainability (Syeda, and Adnan, 2016). Social workers also organize participatory assessment sessions in the form of Rapid Rural Appraisal, Participatory Rural Appraisal for needs and resources identification.

\section{Promoting Women Participation}

Women constitute half of the population of Pakistan and are important stakeholders in development process. Effective disaster risk reduction policy calls for women participation in disaster management. In Pakistan women cannot participate in developmental efforts including disaster risk reduction due to male 
dominancy and prevalent cultural values (International Federation of Red Cross and Red Crescent Societies, 2007). Here the role of social worker is very important in mobilizing the women to equally take part in disaster risk reduction activities at the community level. Social workers can play an important role in providing conducive environment and motivating women to take part in pre and post disaster period. In addition social worker can also build the capacities of women regarding disaster management at the grassroots level (Hossain, 2008).

\section{Mobilization of Volunteers}

Social workers can identify, mobilize and train the volunteers from the affected community to participate in response, relief and rehabilitation activities. These volunteers will identify the most affected and vulnerable communities for in time interventions so that damage to the human lives as well as properties can be minimized (Mathbor, 2007). As the volunteers belong to the same communities therefore they will actively participate and own the interventions.

\section{Capacity Building}

Social workers can perform his/her role by initiating community development activities, organizing training sessions for improving livelihood on sustainable basis. Similarly building the capacity of social work professionals is also the need of the hour for the integration of social, environmental and economic dimensions in theory and practice and to develop curricula to better prepare social workers for the future challenges (Drolet \& Ersing, 2014).

\section{Conclusions}

As the world population is increasing and disasters both natural and man-made continue to occur, nations throughout the globe should be prepared for disasters and better able to deal with its impacts. Governments, donors both national and international are working at various levels in the fields of disaster preparedness, response, recovery and rehabilitation.

Pakistan has also suffered due to the impacts of natural hazards and due to scarcity of resources, lack of awareness and weak institutional machinery for disaster management. Effective disaster management needs well-coordinated efforts on the part of government as well as public. In addition, education both formal and informal, capacity building, and inclusion of all stakeholder i.e. government, community, NGOs and social workers is essential for disaster risk reduction on sustainable basis. Like others stakeholders, professional social work has also accepted the challenge of contributing to the efforts of disaster risk reduction because of its sound body of knowledge, methods and the scope of 
work. In addition social work aims to serve the weaker sections of society i.e. those affected by the natural as well as man-made disaster. Due to the increasing numbers of disasters, the demand for social workers is also increasing in contemporary society. The government departments as well as the donors both national and international are hiring professional social workers for delivering services both in pre and post disaster periods. These professionals are striving to link the affected communities with relevant government as well as nongovernmental organizations for getting maximum assistance for the affected communities.

Social workers deliver their services in different capacities in the pre-and postdisaster period and his/her role is subject to the situation. Social workers perform the role as a motivator, counsellor, community organizer, therapist, advocate, activist, funds raiser/collector and guide etc.

\section{Recommendations}

Social Work profession aims to work for the welfare of individual, group and community. Social workers are always busy in delivering services to the weaker sections of society especially those affected by the sudden incidence. Therefore, social worker's job is very important in the rehabilitation of victims of disaster both natural and man-made. On the basis of the study it is recommended that social workers should be involved in all disaster mitigation and reduction strategies in prior-and post- disaster continuum.

In the context of Pakistani society, the professional social workers should equip themselves with the modern knowledge both theoretical and practical for delivering effective services at the time of emergencies.

In Pakistan the course of Disaster Management \& Rehabilitation should be introduced at BS, M.A, M.Phil and PhD level so that more and more social workers can be produced with up-dated knowledge regarding disaster risk reduction.

Qualified social workers working in government and NGOs sector can play an effective role in disaster relief, recovery and rehabilitation. These professionals need refresher courses in how to deliver services in pre-and post disaster situations.

The educational institutions i.e. Universities and Colleges or Degree Awarding Institutions offering disaster management subject should develop linkages with international and national NGOs working in the domain of disaster management. 


\section{References}

Abarquez, I. \& Murshed, Z. (2004). Community Based Disaster Risk Management: Field Practitioners' Handbook. Asian Disaster Preparedness Centre (ADPC), P.O. Box 4, KlongLuang, Pathumthani 12120, Thailand. Website: www.adpc.ne

Adnan, M. (2014). Pakistan's Crisis Management: Examining Proactive and Reactive Strategies. Journal of Political Studies, vol.21:1, pp.161:177.

Ali, J. (2005). A Critique on Participatory Development. Un-Published Ph.D Dissertation, University of Hull, United Kingdom.

Ali, M. (2017, July 11). Dealing with Disasters. The News International. Retrieved on July12, 2017 from: https:/www.thenews.com.pk/print/ 215719-Dealing-with-disaster

Australian Institute for Disaster Resilience, (2011). Australian Emergency Management Handbook Series: Community Recovery HANDBOOK 2. Third edition. Australian Emergency Management Institute, GEON Impact Printing ISBN 978-1-921152-27-6. Retrieved on July 13, 2017 from: https://www.aidr.org.au/media/1488/handbook-2-community-recovery.pdf.

Dodds, S. \& E. Nuehring (1996). A Primer for Social Work Research on Disaster, Journal of Social Service Research, vol.22:1, pp.27-56.

Drolet, J. \& Ersing, R. (2014, 10 July). Rebuilding Lives Post-Disaster: What is the Role of Social Workers? The Guardian. Retrieved on July 30, 2017 from: https://www.theguardian.com/social-care-network/2014/jul/11/rebuildinglives-post-disaster-role-social-workers

Farquhar, S. \& N. Dobson. (2004). Community and University Participation in Disaster Relief Recovery: An Example from Eastern North Carolina', Journal of Community Practice, vol.12:3/4, pp.203-17.

Fowler, J. (2015). Social Workers Key Players in DRR. United Nations Office for Disaster Risk Reduction (UNISDR).Retrieved on July 29, 2017 from: https://www.unisdr.org/archive/45008

Gillespie, D. (2006). Before a Disaster Strikes. Retrieved on July 08, 2017 from: disahttps://brownschool.wustl.edu/documents/si_disaster_14-17.pdf 
Harding, S. (2007). Man-Made Disaster and Development: The Case of Iraq. International Social Work, vol.50, p.295. DOI: 10.1177/0020872807076041

Hossain, Md. A. (2008). Women's participation in social change decision: A study of two union parishads in Bangladesh. Unpublished M.Phil. Thesis, University of Bergen, Bergen, Norway.

International Federation of Red Cross and Red Crescent Societies. (2007). World Disaster Report Focus on Discrimination. Retrieved on August 22, 2017 from: https://disasterrehabilitation.files.wordpress.com/2011/03/wdr2007english.pdf

Iqbal, I. (2012). Management of 2011 floods in Pakistan. Paper presented at Scientific and Technical Subcommittee 2012, Forty-ninth session (6-17 February). United Nations Office of Outer Space Affairs (OOSA), Vienna. http://www.oosa.unvienna.org/oosa/en/COPUOS/stsc/2012/prese ntations.html

Javadian, R. (2007). Social work responses to earthquake disasters: A social work intervention in Bam, Iran. International Social Work, 50; 334. DOI: $10.1177 / 0020872807076047$.

JICA (2002). Social Capital to Kokusai Kyoryoku: Jizokusuru Seika woMezasite. (In Japanese). Tokyo: Japan International Cooperation Agency.

Loeffler, D.N., D.C. Christiansen, M.B. Tracy, M.C. Secret, R.L. Ersing, S.R. Fairchild \& R. Sutphen (2004) 'Social capital for social work: Toward a definition and conceptual framework', Social Development Issues 26(2/3): 22-38, Lombard, IL: Lyceum Books.

Lyons, K., Hokenstad, T., Pawar, M., Huegler, N. \& Hall, N. (2012). The Sage book of International Social Work. The Sage Publishing Limited, 1 Oliver's Yard 55 City Road London ECIY 1SP

Mathbor, M. G. (2007). Enhancement of Community Preparedness for Natural Disasters: The Role of Social Work in Building Social Capital for Sustainable Disaster Relief and Management. International Social Work, vol.50:3, pp.357-369. DOI: 10.1177/0020872807076049.

Nakagawa, Y \& Shaw, R. (2004). Social Capital: A Missing Link to Disaster Recovery. International Journal of Mass Emergencies and Disasters, vol.22:1, pp.5-34. 
National Disaster Management Authority (2013). .National Disaster Risk Reduction Policy. Ministry of Climate Change Government of Pakistan. Retrieved on August 29, 2017 from: http://www.ndma.gov.pk/plans/ drrpolicy2013.pdf

Pakistan \& UN. (2012). Pakistan Floods 2011- Early Recovery Frame Work, January, 2012. Retrieved on July 08, 2017 from: http://www.pakresponse.info/Portals/0/Key_Docs/Pakistan\%20Early\%20

Recovery\%2 0Framework\%20Floods\%202011_210212.pdf

Pakistan Floods 2011- Early Recovery Frame Work. Retrieved on July 08, 2017 from: http://fscluster.org/pakistan/document/pakistan-floods-2011-earlyrecovery

Provincial Disaster Management Authority (2016). Overview of Natural Disasters 2015 Impact, Response and Managing Risks. Ad.Sense Printing and Advertising, Peshawar, Pakistan.

Pryce, Jo Knox, \& David H. Pryce. (2000). Healing Psychological Wounds of War Veterans: Vet Centres and the Social Contract. Tulane Studies in Social Welfare, vol.21/22, pp.267-283.

Soliman, H.H. \& M.E. Rogge (2002). Ethical Considerations in Disaster Services: A Social Work Perspective, Electronic Journal of Social Work, vol.1:1, Article 10.

Stoesen, L. (2006). Experts Examine Disasters, Disparities, NASW News (5 April) Washington, DC: NASW.

Syeda, M. H. \& Adnan, M. (2016). Rebuilding Lives: Natural Disasters and Role of a Social Worker in Pakistan. Journal of the Research Society of Pakistan, vol.53:2.

The Asia-Pacific Disaster Report .(2012). Reducing Vulnerability and Exposure to Disasters. ESCAP United Nations Building Rajdamnern Nok Avenue 10200 Bangkok -Thailand .www.unescap.org

UNICEF (2011). Disaster Risk Reduction and Education. United Nations Children's Fund United Nations Plaza New York, NY 10017, USA

United Nations International Strategy for Disaster Reduction (2009). 2009 UNISDR Terminology on Disaster Risk Reduction. UNISDR, Geneva Switzerland 
Wahlstrom, M. (2017). Social Work and the Sendai Framework for Disaster Risk Reduction, European Journal of Social Work, vol.20:3, pp.333-336, http://dx.doi.org/10.1080/13691457.2017.1314936

World Health Organization (2015). Managing Disaster Risks in Communities. A Community-Based Approach to Disaster Risk Reduction (Training Manual for the Trainers of Cluster Representatives and Volunteers). World Health Organization. Regional Office for the Eastern Mediterranean. ISBN: 97892-9021-906-4 ISBN: 978-92-9021-907-1 (online) (NLM Classification: WA 295. Retrieved on July 30, 2017 from: http://applications.emro.who. int/dsaf/EMROPUB_2015_EN_1881.pdf

Yamamura, E. (2010). Effects of Interactions among Social Capital, Income and Learning from Experiences of Natural Disasters: A Case Study from Japan. Regional Studies, vol.44:8, pp.1019-1032.

Yueh, C.C. (2003). Social Workers' Involvement in Taiwan's 1999 Earthquake Disaster aid: Implications for Social Work Education', Online Journal of Social Work and Society, vol.1:1, pp.1-22.

Sajjad Hussain is Ph.D Scholar in the Department of Social Work, University of Peshawar, Khyber Pakhtunkhwa, Pakistan.

Dr. Muhammad Ibrar is an Assistant Professor in the Department of Social Work, University of Peshawar, Khyber Pakhtunkhwa, Pakistan.

Hamid Alam is an Assistant Professor in the Department of Social Work, University of Malakand, Chakdara Dir Lower, Khyber Pakhtunkhwa, Pakistan. 